IFAS Extension

\title{
Diagnosing Herbicide Injury in Corn ${ }^{1}$
}

\section{Sarah Berger, Jason Ferrell, and Peter Dittmar ${ }^{2}$}
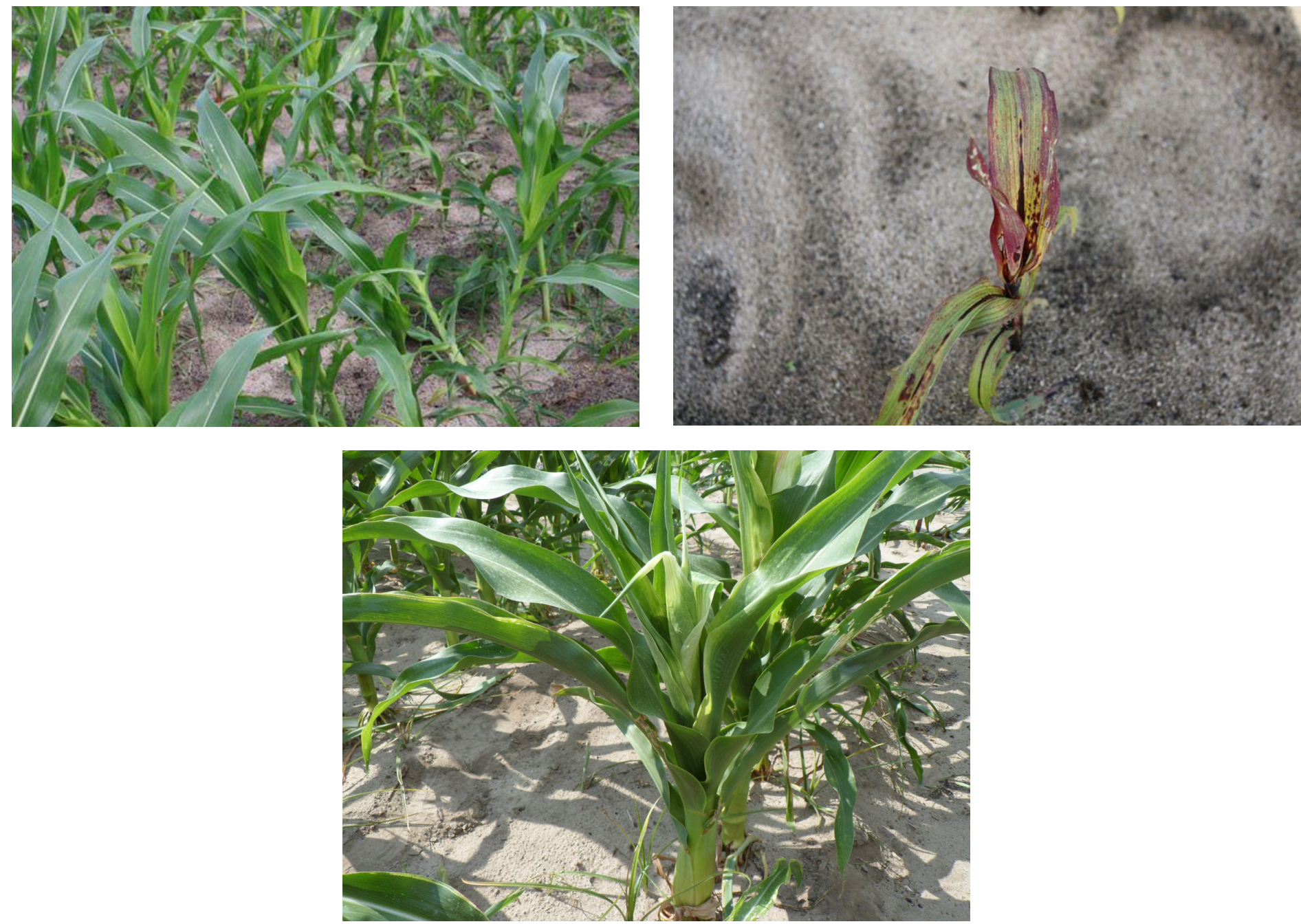

1. This document is SS-AGR-365, one of a series of the Agronomy Department, Florida Cooperative Extension Service, Institute of Food and Agricultural Sciences, University of Florida. Original publication date January 2013. Please visit the EDIS website at http://edis.ifas.ufl.edu.

2. Sarah Berger, graduate assistant, Agronomy Department; Jason Ferrell, associate professor, Agronomy Department; and Peter Dittmar, assistant professor, Horticultural Sciences Department; Florida Cooperative Extension Service, Institute of Food and Agricultural Sciences, University of Florida, Gainesville, FL 32611.

The use of trade names in this publication is solely for the purpose of providing specific information. UF/IFAS does not guarantee or warranty the products named, and references to them in this publication do not signify our approval to the exclusion of other products of suitable composition. All chemicals should be used in accordance with directions on the manufacturer's label.

The Institute of Food and Agricultural Sciences (IFAS) is an Equal Opportunity Institution authorized to provide research, educational information and other services only to individuals and institutions that function with non-discrimination with respect to race, creed, color, religion, age, disability, sex, sexual orientation, marital status, national origin, political opinions or affiliations. U.S. Department of Agriculture, Cooperative Extension Service, University of Florida, IFAS, Florida A\&M University Cooperative Extension Program, and Boards of County Commissioners Cooperating. Nick T. Place, Dean 


\section{Amino Acid Synthesis Inhibitors (ALS Inhibitors)}

Mechanism of Action: The ALS-inhibiting herbicides block the acetolactate synthase (ALS) enzyme. The ALS enzyme is responsible for the formation of essential amino acids in the plant (isoleucine, leucine, and valine). Without these amino acids, proteins (complex molecules that control all plant functions) cannot be formed, and the plant slowly dies.

Behavior in Plants: These herbicides are absorbed by roots and leaves and move extensively in the plant. Plants may take two weeks to develop symptoms depending on weather conditions (temperature, soil moisture, etc.) and the overall rate of growth.

Symptoms: Pre-emergence injury on corn begins with stunted growth and yellowing in the youngest leaves. Leaves take on a lime or light green color, and leaf veins generally turn red. The yellowing is followed by tissue death some days later. Root malformation can also occur, which causes a "bottle-brush"-look because of very short roots.

\section{Herbicides with this mode of action:}

Imidazolinones: Imazapyr (Arsenal), Imazapic (Cadre), Imazethapyr (Pursuit), Imazaquin (Scepter)

Sulfonylureas: Chlorimuron (Classic), Halosulfuron*, Metsulfuron, Nicosulfuron* (Accent), Trifloxysulfuron (Envoke)

Pyrimidinylthiobenzoic acid: Pyrithiobac (Staple)

*indicates herbicide labeled for use in corn

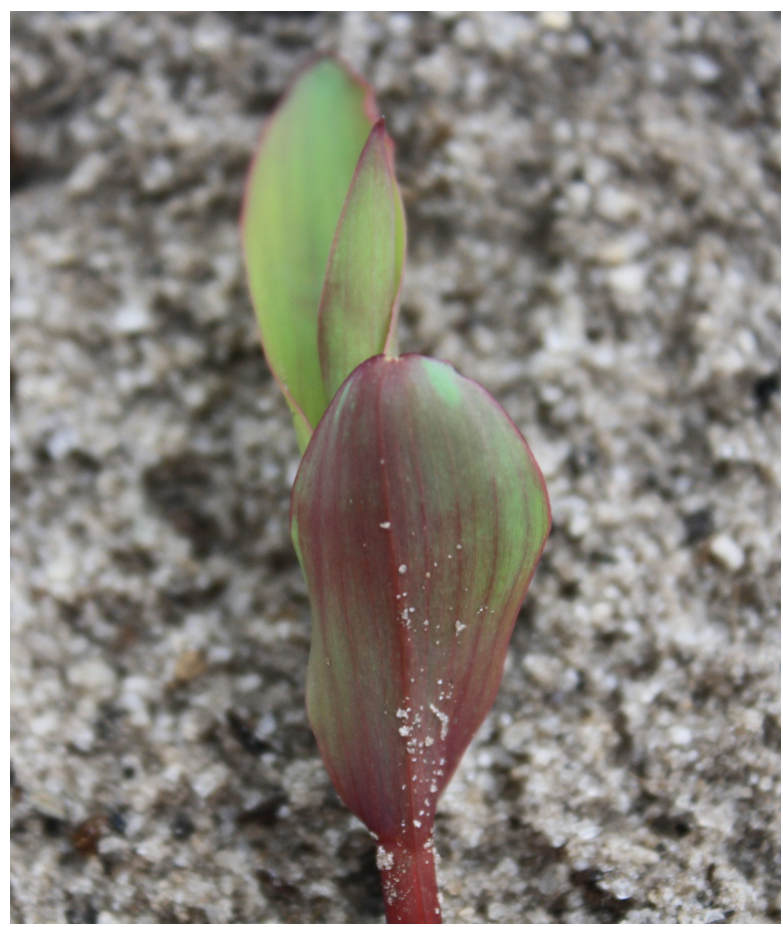

Figure 1. Injury from Imazaquin applied pre-emergence. Note the characteristic red veins.

Credits: Sarah Berger

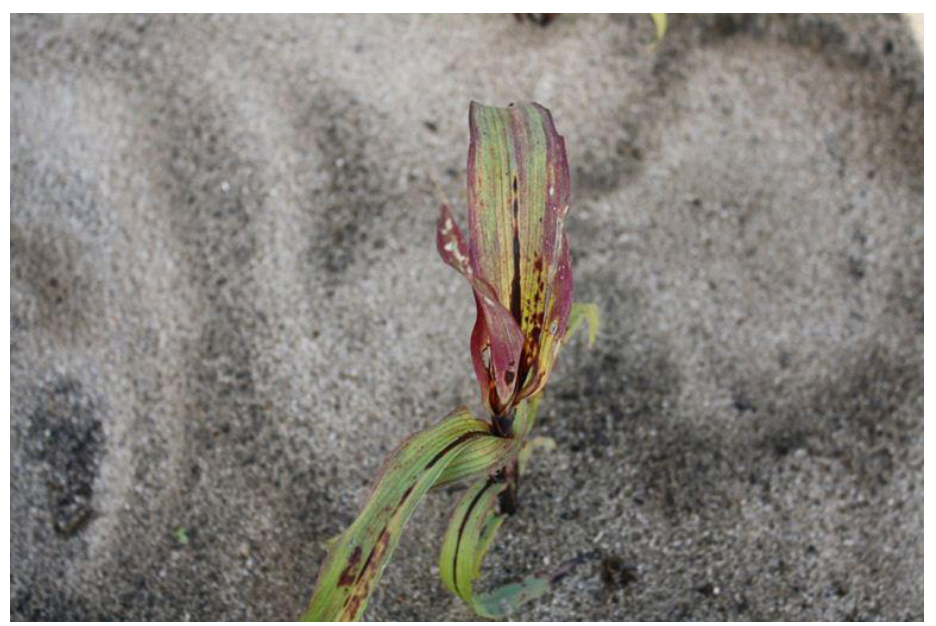

Figure 2. Imazaquin injury several days after a post-emergence application. Tissue death is becoming apparent.

Credits: Sarah Berger 


\section{Growth Regulators}

Mechanism of Action: Auxin is a plant hormone that controls plant growth. The growth regulator herbicides look very similar to auxin, and the plant is unable to distinguish the difference. This overload of hormone causes the plant to grow in an uncontrollable fashion and results in disruption of numerous essential plant processes (e.g., photosynthesis, transpiration, cell division, etc.). Corn is generally tolerant to auxin herbicides, but application rate and timing must be closely monitored or unacceptable levels of injury can result.

Behavior in Plants: These herbicides are highly mobile in the plant and tend to accumulate in growing points.

Symptoms: Symptoms of herbicide injury in corn are malformed brace roots, brittle stems, plants that do not grow upright, and stunting.

Herbicides with this mode of action: 2,4- $\mathrm{D}^{*}$, Dicamba ${ }^{*}$, Picloram, Triclopyr, Aminopyralid (Milestone), Quinclorac (Drive), Clopyralid (Stinger)

*indicates herbicide labeled for use in corn

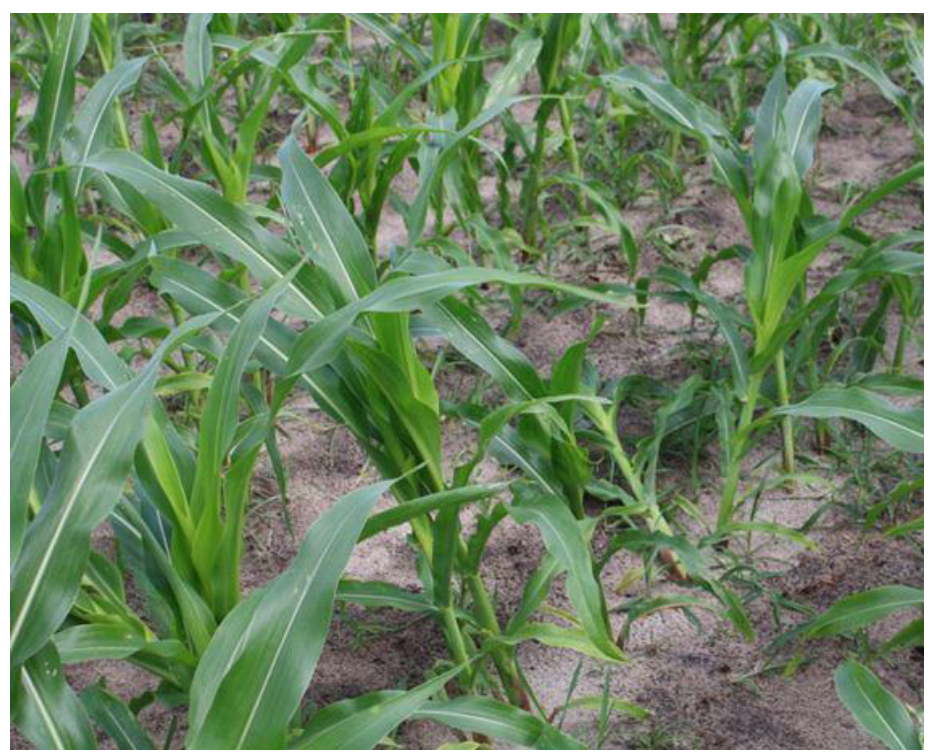

Figure 3. Corn plants leaning over after 2,4-D was applied too late in the season.

Credits: Sarah Berger

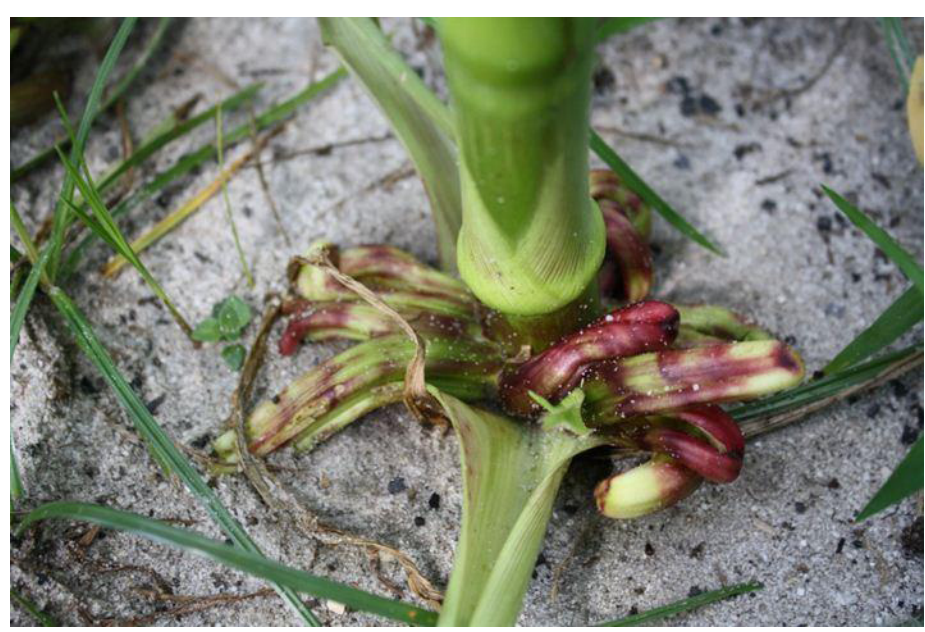

Figure 4. Malformed brace roots following a 2,4-D application. Credits: Sarah Berger 


\section{Pigment Inhibitors}

Mechanism of Action: Chlorophyll captures light and allows it to be converted to usable energy. But chlorophyll can be damaged if too much sunlight is present, so carotenoid pigments absorb this excess energy and protect chlorophyll. Pigment-inhibiting herbicides act by blocking the formation of carotenoids so that chlorophyll is destroyed by light energy from the sun. These herbicides can be applied pre-emergence or post-emergence.

Behavior in Plants: With no carotenoid pigments produced, the chlorophyll is destroyed, leaving no leaf pigments of any kind.

Symptoms: The main sign of injury is bleached-white foliage. Varying levels of bleaching can occur, depending on the herbicide dose. Affected plants often recover from minor bleaching, but more severe bleaching is rapidly followed by tissue death.

Herbicides with this mode of action: Norflurazon (Solicam), Mesotrione (Callisto), Tembotrione* (Laudis), Isoxaflutole $^{\star}$ (Balance), Clomazone (Command)

${ }^{*}$ indicates herbicide labeled for use in corn

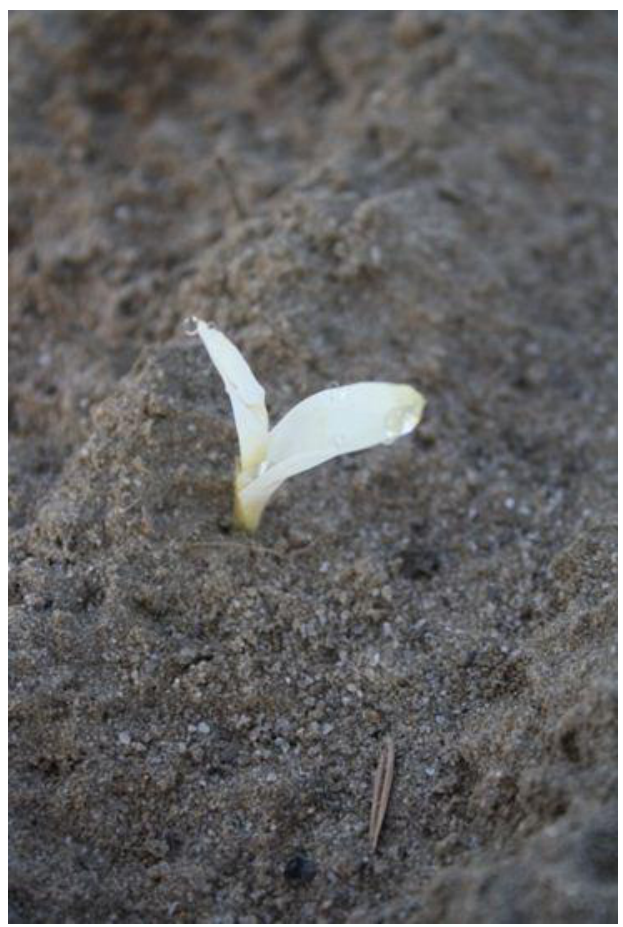

Figure 5. Corn seedling exhibiting bleaching after pre-emergent Clomazone application.

Credits: Peter Dittmar

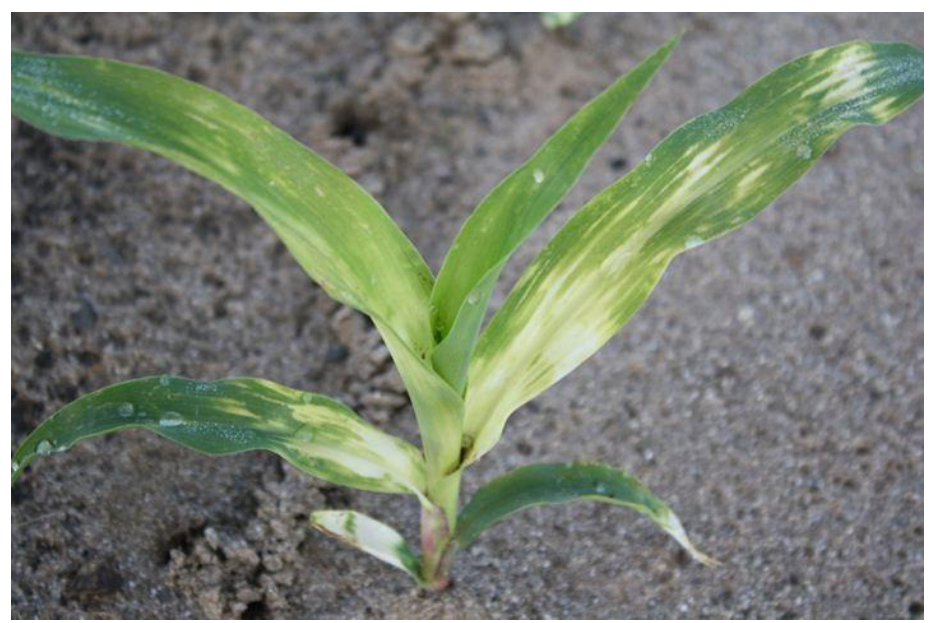

Figure 6. Less severe injury caused by Clomazone application. Credits: Peter Dittmar 


\section{Cell Membrane Disruptors}

Mechanism of Action: The cell membrane disruptor herbicides (also called the PPO herbicides) inhibit an enzyme that manufactures chlorophyll. Consequently, a pre-chlorophyll molecule capable of accepting light energy accumulates, and it cannot be passed along to the photosynthesis process. As a result, energy builds up in the leaf until cell membranes are destroyed. Rapid burning and death of leaves occur within 1-3 days, depending on light and weather conditions.

Behavior in Plants: Although many herbicides in this group are labeled only for pre-emergence applications, all of these herbicides possess foliar activity as well.

Symptoms: When applied pre-emergence, these herbicides can cause burning of tissue or failed emergence. These herbicides cause bronzing and burning in a speckled pattern when applied post-emergence. The herbicide will accumulate in the midvein, causing it to turn red/black and break. Injury from cell membrane disruptor herbicide drift can be easily confused with paraquat injury.

Herbicides with this mode of action: Flumioxazin (Valor), Fomesafen (Reflex), Lactofen (Cobra), Carfentrazone (Aim), Acifluorfen (Ultra Blazer, Storm)

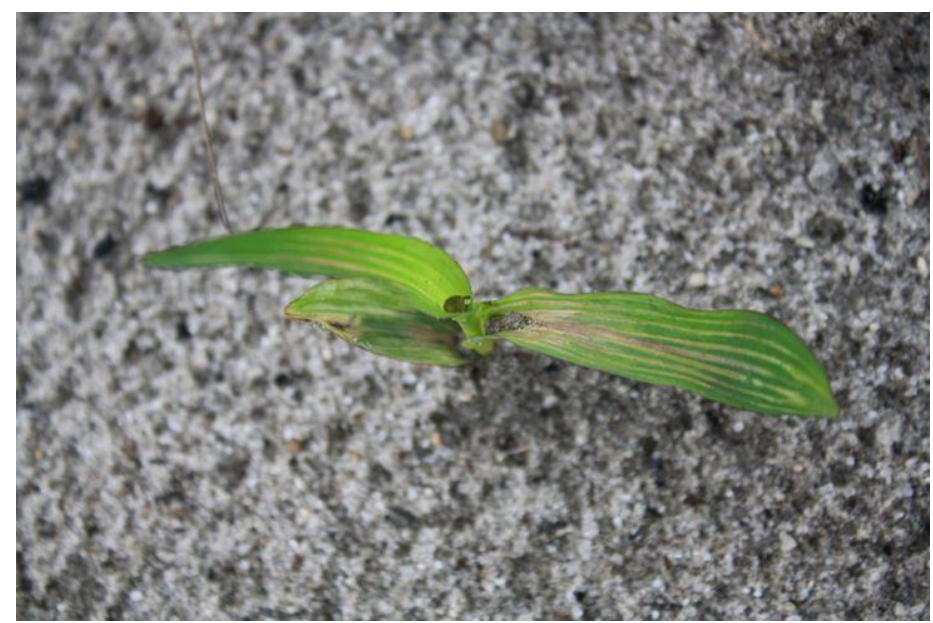

Figure 7. Injury from a pre-emergent Fomesafen application. Note dead tissue in the leaves.

Credits: Sarah Berger

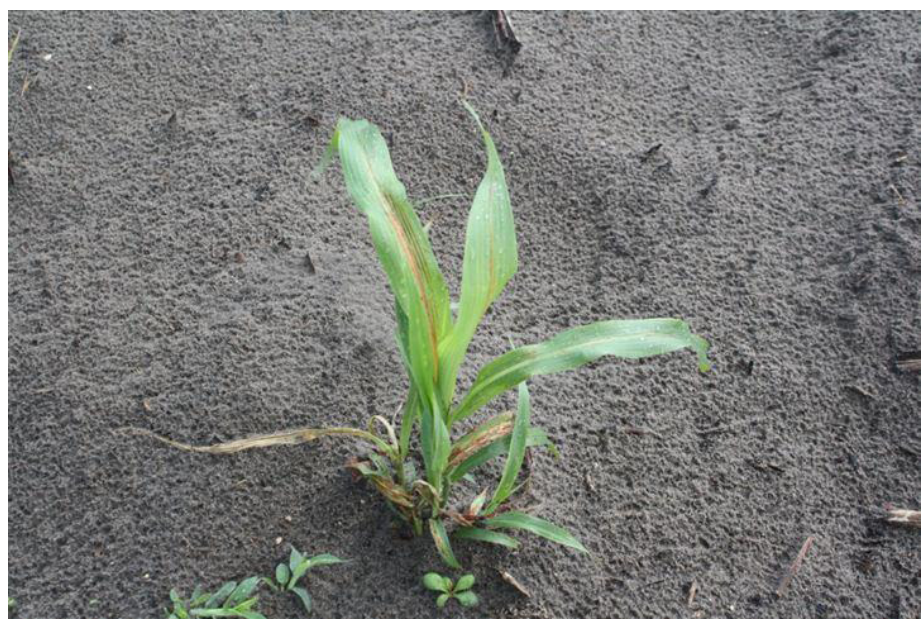

Figure 8. Fomesafen injury. Note tissue death in the leaf midvein. Credits: Peter Dittmar

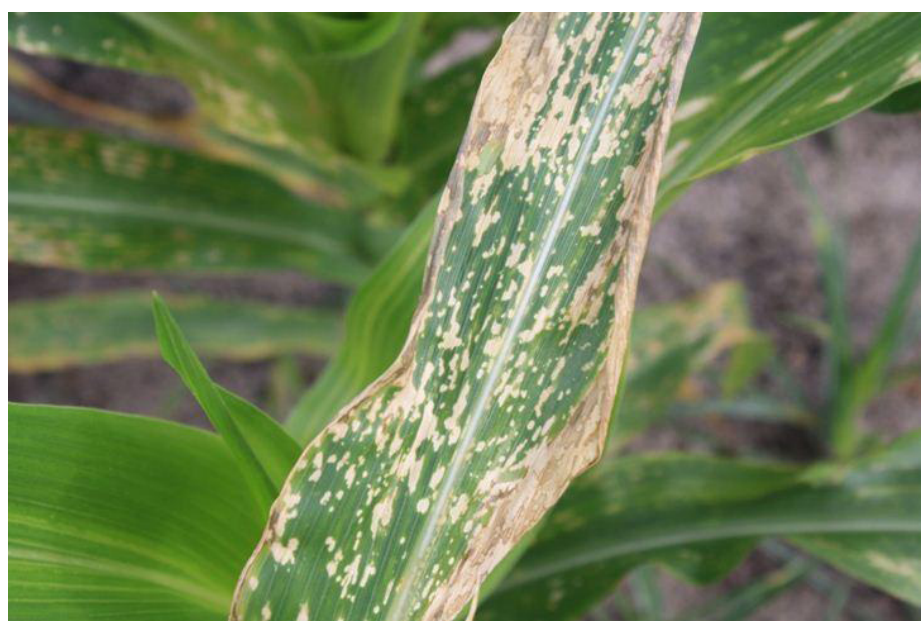

Figure 9. Injury from a post-emergence application of Fomesafen. Note the speckled appearance of leaves.

Credits: Sarah Berger 


\section{Seedling Growth Inhibitors}

There are two types of seedling growth inhibitors: root inhibitors and shoot inhibitors. These two have different modes of action, but both control plants at the seedling stage below the ground.

\section{Dinitroanalines}

Mechanism of Action: These herbicides (also known as the DNAs or the yellow herbicides) inhibit root formation in susceptible plants. Root inhibition occurs when the herbicide blocks the process of mitosis (cell division) in the root tip. Affected plants eventually die of drought stress, regardless of soil water status, because the plants will not have the ability to develop sufficient root structure to support the water needs of the developing leaf and shoot.

Behavior in Plants: The yellow herbicides do not move in plants and only work at the root tip. Roots that extend beyond the treated zone will regain normal growth and development.

Symptoms: These herbicides can cause short club-like roots in corn, and plants that emerge will be stunted.

Herbicides with this mode of action: Pendimethalin* (Prowl), Trifluralin (Treflan), Ethafluralin (Sonalan)

${ }^{*}$ indicates herbicide labeled for use in corn

\section{Chloroacetamides}

Mechanism of Action: These herbicides inhibit several plant processes such as lipid and protein formation.

Behavior in Plants: Chloroacetamides are absorbed into the shoots of emerging plants. The herbicide must be

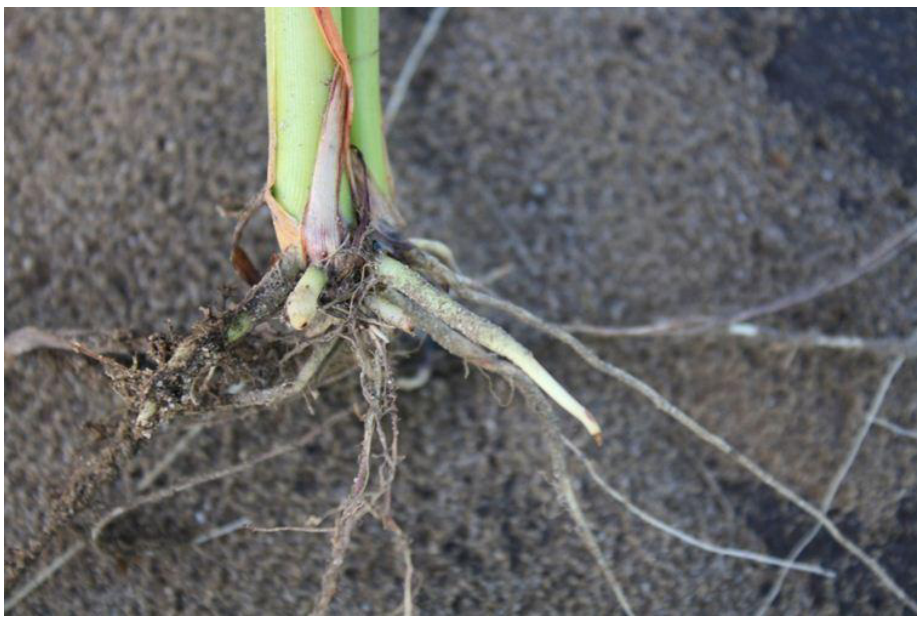

Figure 10. Injury caused by Pendimethalin. Note short roots. Credits: Sarah Berger present during emergence to be effective. No activity will be observed from later applications to emerged weeds.

Symptoms: Corn injury symptoms include stunted growth and failed emergence. Injured leaves can be malformed or fail to unroll properly, called "buggy-whipping."

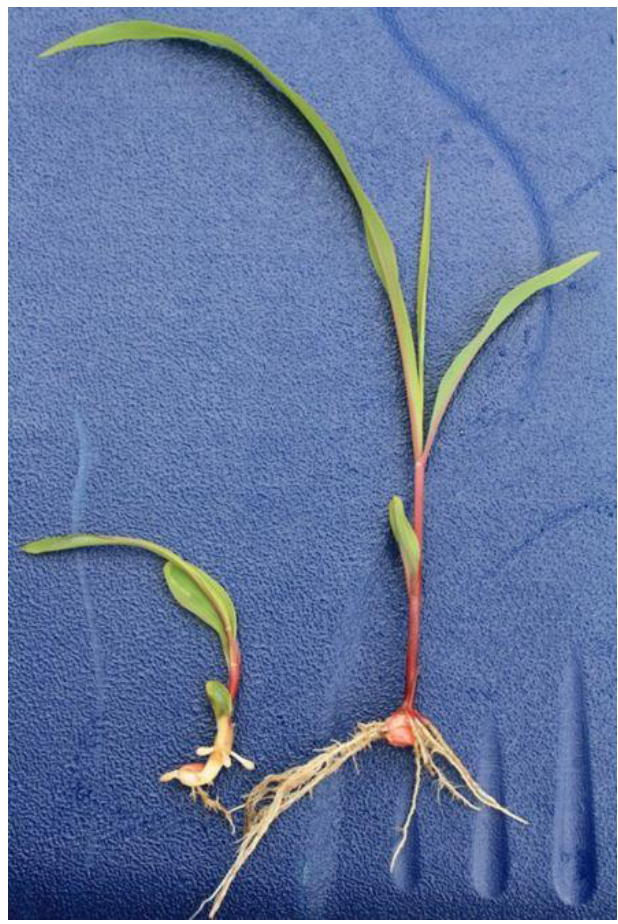

Figure 11. Pendimethalin injury. The plant on the left has short roots and stunted growth compared to the normal corn plant on the right. Credits: Sarah Berger

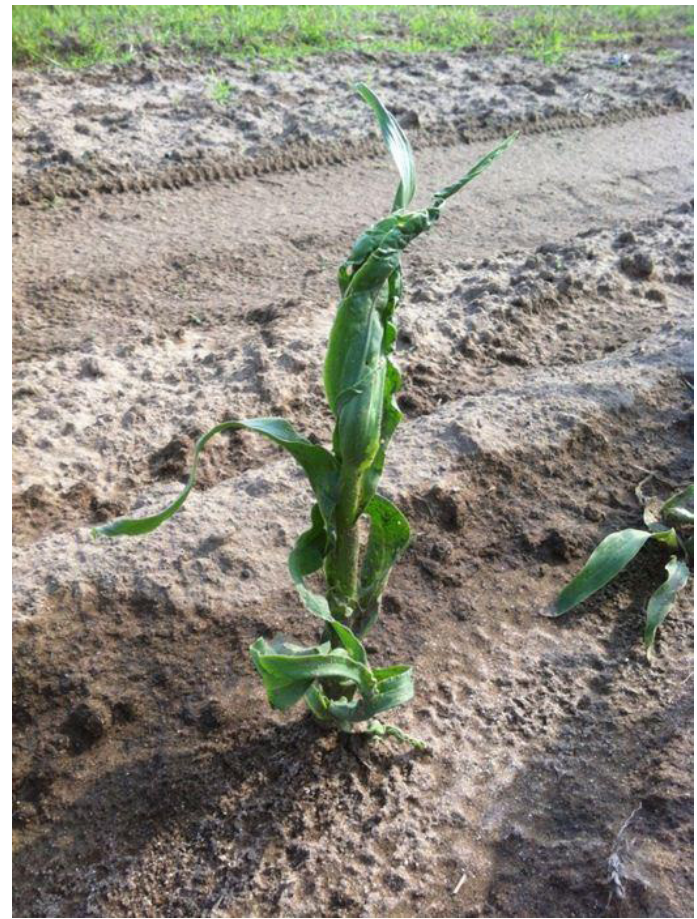

Figure 12. Malformed corn leaves after S-metolachlor application. This injury is referred to as buggy-whipping.

Credits: Peter Dittmar 
Herbicides with this mode of action: S-metolachlor* (Dual), Alachlor (Intro), Acetochlor* (Warrant, Harness), Pyroxasulfone $^{*}$ (Zidua)

${ }^{*}$ indicates herbicide labeled for use in corn

\section{Lipid Synthesis Inhibitors (ACCase Inhibitors)}

Mechanism of Action: The herbicides inhibit an enzyme (ACCase) that produces lipids, which are used to build cell membranes. Although all plants contain an ACCase enzyme, broadleaf and grass plants have distinctly different types of this enzyme. ACCase-inhibiting herbicides cannot bind to this enzyme in broadleaf plants, rendering these plants totally immune to the herbicide. Conversely, almost all grasses, including corn, are sensitive. The ACCaseinhibiting herbicides do not have soil activity.

Behavior in Plants: ACCase inhibitors move throughout the plant, although they only affect grasses.

Symptoms: Corn is very sensitive to ACCase herbicides and will exhibit red tissue and dead growing points.

Herbicides with this mode of action: Sethoxydim (Poast), Clethodim (Select), Fluazifop (Fusilade), Quizalofop (Assure II)

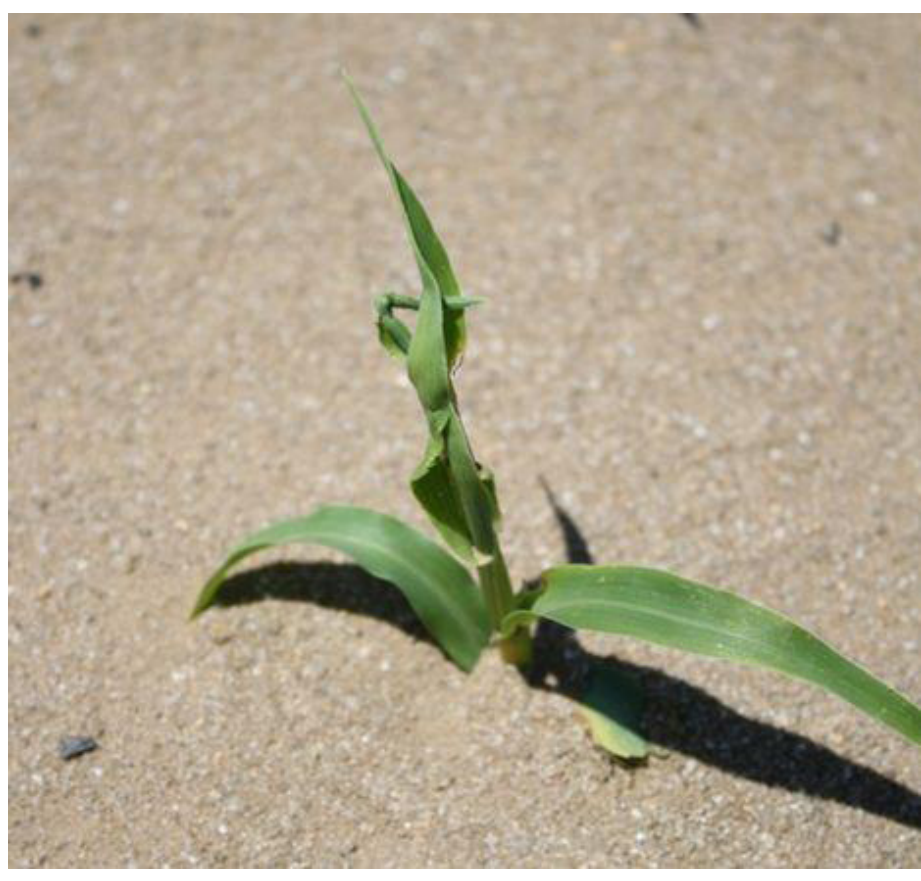

Figure 13. S-metolachlor injury causing leaf disfiguration. Credits: Peter Dittmar

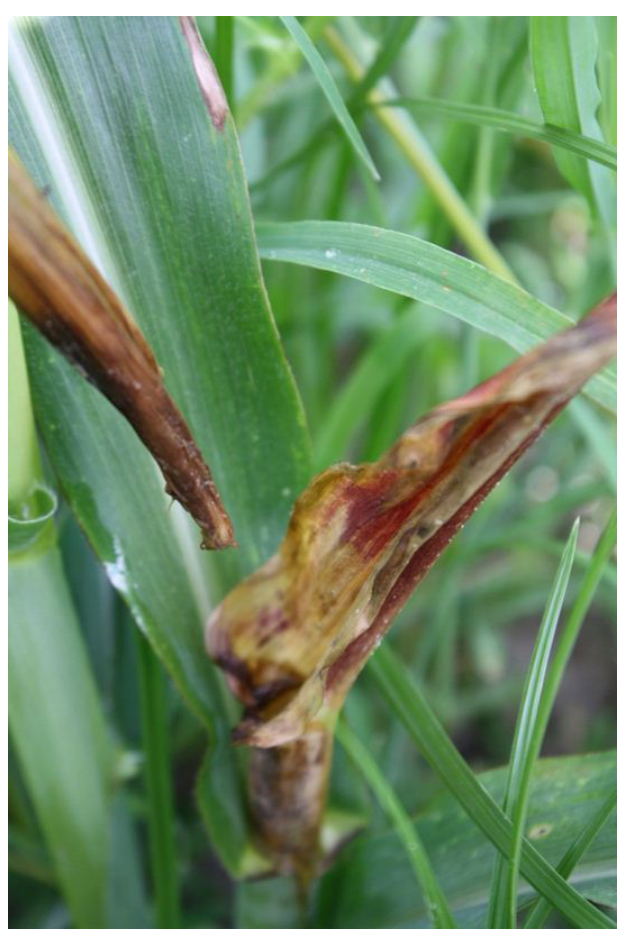

Figure 14. Corn injury caused by a Clethodim application. Note the dead growing point that is easily removed from leaf whorl. Credits: Sarah Berger 


\section{Glufosinate}

Mechanism of Action: Glufosinate inhibits the activity of the enzyme that detoxifies ammonia in the leaf. Inhibiting this enzyme leads to accumulation of toxic levels of ammonia within the cell. The buildup of ammonia quickly leads to multisystem failure within the photosynthesis pathway and causes irreversible cell damage.

Behavior in Plants: Glufosinate has no soil activity. It only affects plant tissue that it contacts.

Symptoms: This is a foliar-applied herbicide with contact activity (limited movement within the plant). Yellowing and leaf wilting are general symptoms, followed by tissue death. Lesions or burning can be present on affected tissue after several days.

Herbicides with this mode of action: Glufosinate (Liberty)

\section{Paraquat}

Mechanism of Action: Paraquat is a post-emergence herbicide with contact foliar activity. It is rapidly absorbed by green tissue and inhibits photosynthesis. Paraquat causes the formation of radical oxygen, which is toxic to plant cell membranes, within the chloroplast.

Behavior in Plants: Paraquat does not move within the plant and only acts on tissue it contacts.

Symptoms: Paraquat causes rapid leaf burning on all species present at the time of application. Paraquat injury can be confused with injury caused by cell membrane disruptors or glufosinate. Injury symptoms of paraquat, cell membrane disruptors, and glufosinate are almost indistinguishable. The only difference between the three is that paraquat injury will generally appear within one day of application, whereas cell membrane disruptors and glufosinate may require a longer amount of time to develop symptoms.

Herbicides with this Mode of Action: Paraquat (Gramoxone)

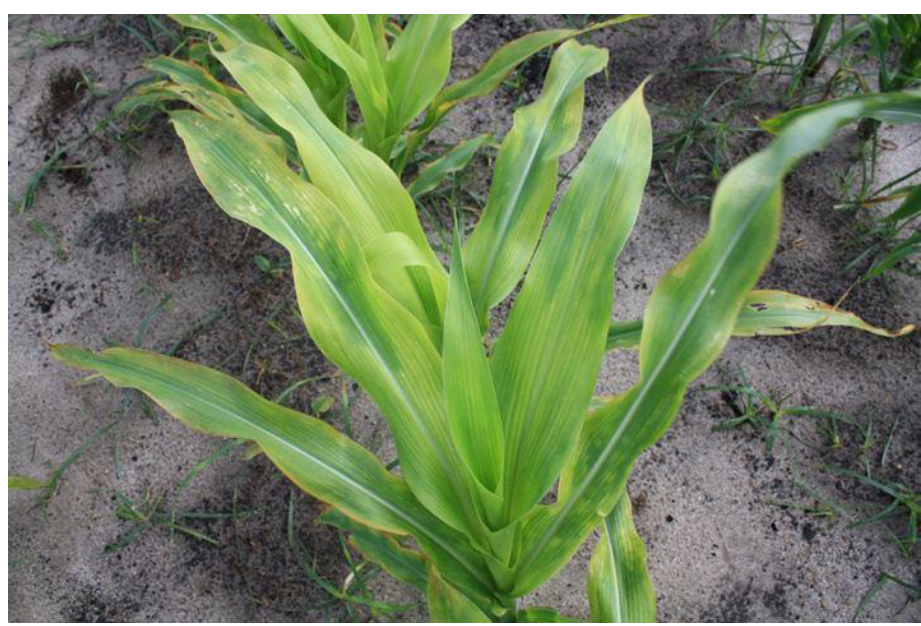

Figure 15. Yellowing of leaves following a Glufosinate application. Depending on application rate, plants will become brown within 3-5 days following these symptoms.

Credits: Sarah Berger

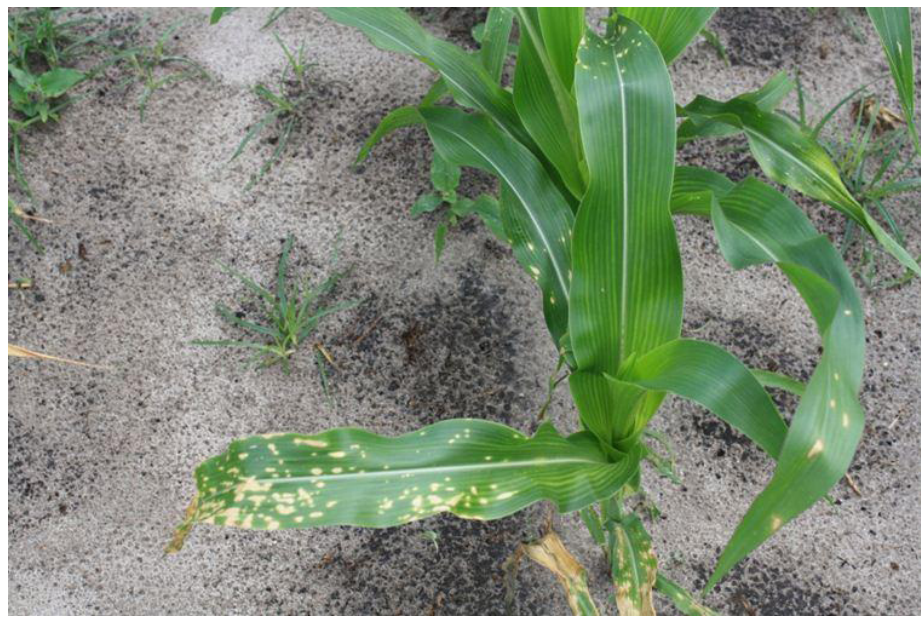

Figure 16. Paraquat injury due to drift. Note dead tissue in spots on leaves.

Credits: Sarah Berger 


\section{Organophosphate Interaction}

Mechanism of Action: Organophosphates are a group of insecticides commonly used in-furrow for insect and nematode management. Turbofos (Counter) is one of the most common examples. These insecticides do not injure the plant, but they can interfere with how the corn plant processes certain herbicides. In particular, if corn has received turbofos at planting, applying ALS-inhibiting herbicides can result in moderate to severe injury.

Behavior in Plants: ALS-inhibiting herbicides must be rapidly broken down within the plant, or the corn will sustain injury. Therefore, the presence of turbofos (or other organophosphate insecticides) can slow the corn plant's ability to break down these herbicides. When the corn plant cannot metabolize ALS-inhibiting herbicides, injury symptoms can occur. More injury can be expected if the herbicide is applied during cool weather.

Symptoms: The most common symptoms are shortened internode length and "lime"-colored foliage. Some bleaching in the whorl can occur, but is less common. Under severe conditions where several nodes are involved, the plant can take on a "pineapple" appearance because several nodes are spaced only a few inches apart.

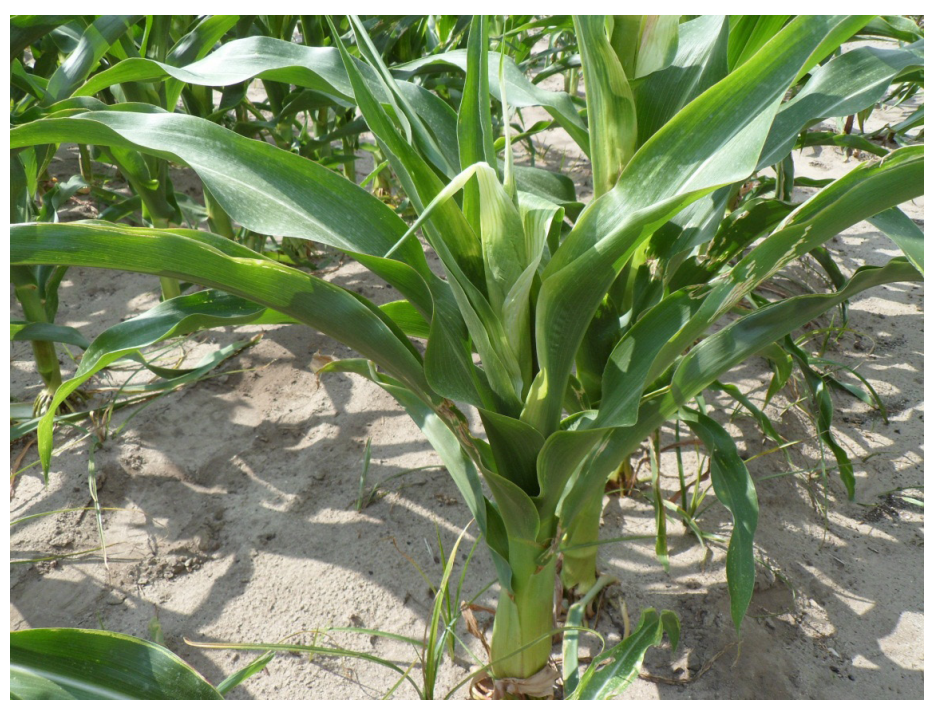

Figure 17. Shortened internodes cause "pineapple"-looking corn. Also, foliage is lime green in color.

Credits: Jason Ferrell 